\title{
Teknologi Pembuatan Kerupuk Berbasis Singkong Di Posdaya Muslimatan Ar-Rahman Desa Candijati Kabupaten Jember Dalam Upaya Pengentasan Kemiskinan
}

\author{
Gatot Subroto, Tri Handoyo dan Ayu Puspita Arum \\ Universitas Jember \\ ayu.puspita.arum.25@gmail.com
}

\begin{abstract}
Abstrak
Kegiatan ini bertujuan untuk menumbuhkan dan meningkatkan kondisi kesejahteraan masyarakat, melalui pemberdayaan perempuan di desa untuk meningkatkan pendapatan keluarga. Metode ini melibatkan konseling produksi kerupuk singkong, pengantar serta menyediakan peralatan produksi dan konseling tentang ekonomi dan usaha kecil produksi kerupuk singkong higienis bersertifikat P-IRT. Kesimpulan dari kegiatan ini adalah: (1) melatih produksi kerupuk singkong menggunakan teknologi boiler yang tepat untuk meningkatkan pendapatan, kesejahteraan anggota kelompok, dan membuka lapangan kerja baru. (2) Produk kerupuk singkong higienis dihasilkan lebih higienis dengan kemasan yang baik (3) Meningkatkan produksi kerupuk singkong dari 20 hingga 50 bungkus.
\end{abstract}

Kata kunci: pemberdayaan, teknologi boiler yang tepat dan kerupuk singkong

\section{Analisis Situasi}

\section{PENDAHULUAN}

Desa Candijati Kecamatan Arjasa merupakan salah satu desa yang memiliki tingkat keluarga miskin yang tinggi, sehingga perlu mendapatkan perhatian khusus dalam membina masyarakat, khususnya dengan memberdayakan wanita di desa tersebut. Dusun Krajan Timur Desa Candijati Kecamatan Arjasa terletak pada ketinggian daratan sedang, yaitu sekitar $150 \mathrm{~m}$ di atas permukaan air laut. Jarak Desa Candijati dari ibu kota kecamatan Arjasa sekitar 1,5 km dengan waktu tempuh sekitar 10 menit menggunakan kendaraan bermotor. Jarak desa dari Kota Kabupaten Jember sekitar $20 \mathrm{~km}$ dengan waktu temput sekitar 25 menit. Berdasarkan data BPS kabupaten Jember tahun 2014, curah hujan di Desa Candijati rata-rata mencapai $2.700 \mathrm{~mm}$, terbanyak terjadi pada bulan September hingga mencapai Januari.

Sampai saat ini, jumlah penduduk Desa Candijati mencapai 1.812 KK yang meliputi 782 KK tercatat sebagai keluarga Pra-Sejahtera, 361 KK sebagai Keluarga Sejahtera I, 215 KK sebagai Keluarga Sejahtera II, 106 KK sebagai Keluarga Sejahtera III, 100 KK sebagaiKeluarga Sejahtera Plus. Penduduk usia produktif pada usia 20-49 tahun Desa Candijati sekitar 3.337 atau hampir 48,9 $\%$. Hal ini merupakan modal berharga bagi pengadaan tenaga produktif dan SDM. Apabila golongan Keluarga Pra-Sejahtera dan golongan I dimasukan sebagai golongan miskin, maka Desa Candijati termasuk dalam Desa Keluarga Miskin dengan jumlah sekitar 43.16\%.

Universitas Jember sebagai salah satu perguruan tinggi negeri di Jember, telah melakukan berbagai upaya untuk meningkatkan kesejahteraan masyarakat dengan membentuk Posdaya (Pos Pemberdayaan Keluarga) di Dusun Krajan Timur, Desa Candijati dengan nama Posdaya Muslimat Ar-Rahman melalui penerjunan mahasiswa yang telah memprogram Kuliah Kerja Nyata (Gambar 1). Posdaya Muslimat Ar-Rahman merupakan kelompok ibu-ibu yang termasuk dalam keluarga miskin, dan saat ini memulai mengembangkan produksi krupuk dalam usaha meningkatkan kesejahteraan keluarga. 
Kelompok Wanita Muslimatan Ar-Rahman adalah salah satu bentuk organisasi yang bertujuan untuk memberdayakan wanita dalam usaha meningkatkan kesejahteraan keluarga sehingga mampu keluar dari masalah kemiskinan (keluarga Pra-sejahtera). Kelompok wanita tersebut merupakan Binaan Lembaga Penelitian Universitas Jember melalui program Pos Pemberdayaan Keluarga (Posdaya) memiliki kegiatan usaha produksi krupuk yang masih relatif sangat kecil dan cenderung mengalami kemunduran, karena sarana produksi yang sangat minim serta kelembagaan yang belum tertata dengan baik.

Kegiatan produksi krupuk yang telah berjalan saat ini masih mengalami banyak kendala, seperti: (1) kelompok posdaya masih membutuhkan pendampingan dalam upaya penguatan kelembagaan, (2) kelompok keluarga pra-sejahtera memiliki kapasitas pengetahuan yang rendah dalam bidang pengembangan usaha, (3) kurangnya keterampilan (daya inovasi dan kreatifitas) kelompok dalam memproduksi krupuk, menyebabkan produk krupuk sangat rendah (kurang dari $20 \mathrm{~kg}$ per hari dan tidak menarik).

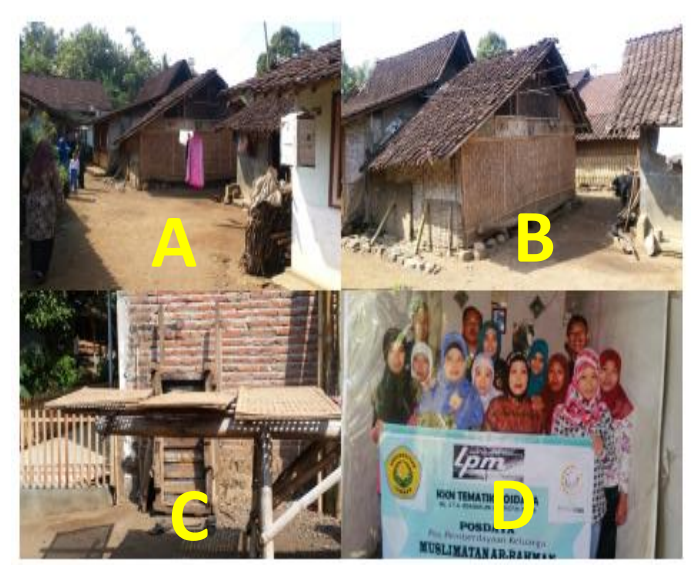

Gambar 1. A dan B. Kondisi beberapa keluarga anggota kelompok Muslimat Ar-Rahman, C. Peralatan jemur yang telah dimiliki kelompok, D. Program KKN yang telah dilaksanakan Universitas Jember dengan rangka memberdayakan masyarakat.

\section{Tujuan dan Manfaat}

Berdasarkan kondisi kelompok Muslimatan Ar-Rahman tersebut, diharapkan program Iptek Bagi Masyarakat ini dapat: (1) membantu pengembangan kelompok wanita tersebut menjadi lebih mandiri secara ekonomi, (2) menciptakan kondisi yang harmonis antar anggota kelompok sehingga terjalin kehidupan masyarakat yang nyaman dan tentram, (3) meningkatkan kapasitas anggota kelompok dengan bekal keterampilan berpikir, membaca, menulis dan keterampilan lain berkaitan dengan produksi krupuk yang telah dijalankan saat ini.

Bebarapa kegiatan yang harus diselenggarakan dalam usaha mencapai harapan tersebut antara lain: (1) memberikan penyuluhan tentang manajemen organisasi dan pemberdayaan kelompok, (2) meningkatkan kapasitas pengetahuan anggota tentang produksi krupuk yang higienis, (3) memberikan pelatihan tentang proses pembuatan krupuk skala rumah tangga, (4) memberikan bantuan peralatan untuk produksi krupuk kepada beberapa anggota muslimatan sebagai stimulasi atau percontohan.

Program Teknologi Pembuatan Krupuk Berbasis Singkong di Posdaya Muslimatan ArRahman Desa Candijati Kabupaten Jember Dalam Upaya Pengentasan Kemiskinan, diharapkan dapat mengatasi permasalah di desa tersebut serta dapat menyediakan lapangan kerja secara luas dan upaya percepatan pengentasan kemiskinan dapat tercapai.

Manfaat yang diharapkan dari kegiatan ini seperti berikut.

- Meningkatkan pendapatan, kesejahteraan anggota kelompok Posdaya dan membuka lapangan kerja baru.

- Menghasilkan produk kerupuk singkong yang lebih higienis. 
- Meningkatkan kapasitas produksi kerupuk singkong.

\section{LANDASAN TEORI}

\section{Definisi Pemberdayaan}

Pemberdayaan sebagai proses mengembangkan,memandirikan,menswadayakan, memperkuat posisi tawar menawar masyarakat lapisan bawah terhadap kekuatan-kekuatan penekan di segala bidang dan sektor kehidupan (Sutoro, 2002). Konsep pemberdayaan (masyarakat desa) dapat dipahami juga dengan dua cara pandang. Pertama, pemberdayaan dimaknai dalam konteks menempatkan posisi berdiri masyarakat. Posisi masyarakat bukanlah obyek penerima manfaat (beneficiaries) yang tergantung pada pemberian dari pihak luar seperti pemerintah, melainkan dalam posisi sebagai subyek (agen atau partisipan yang bertindak) yang berbuat secara mandiri. Berbuat secara mandiri bukan berarti lepas dari tanggungjawab negara. Pemberian layanan publik (kesehatan, pendidikan, perumahan, transportasi dan seterusnya) kepada masyarakat tentu merupakan tugas (kewajiban) negara secara given. Masyarakat yang mandiri sebagai partisipan berarti terbukanya ruang dan kapasitas mengembangkan potensi-kreasi, mengontrol lingkungan dan sumber dayanya sendiri, menyelesaikan masalah secara mandiri, dan ikut menentukan proses politik di ranah negara. Masyarakat ikut berpartisipasi dalam proses pembangunan dan pemerintahan (Sutoro, 2002).

Permendagri RI Nomor 7 Tahun 2007 tentang Kader Pemberdayaan Masyarakat, dinyatakan bahwa pemberdayaan masyarakat adalah suatu strategi yang digunakan dalam pembangunan masyarakat sebagai upaya untuk mewujudkan kemampuan dan kemandirian dalam kehidupan bermasyarakat, berbangsa dan bernegara (Pasal 1, ayat (8) ). Inti pengertian pemberdayaan masyarakat merupakan strategi untuk mewujudkan kemampuan dan kemandirian masyarakat.

\section{Kajian Teknologi Pembuatan Kerupuk}

Kerupuk merupakan suatu jenis makanan kecil yang sudah lama dikenal oleh sebagian besar masyarakat Indonesia. Kerupuk dapat dikonsumsi sebagai makanan selingan maupun sebagai variasi dalam lauk pauk. Sebagai komoditi dagangan kerupuk termasuk kedalam jenis produk industri yang mempunyai potensi cukup baik. Saat ini pemasarannya berkembang tidak hanya di dalam negeri, tetapi juga di luar negeri seperti Belanda, Singapura, Hongkong, Jepang, Suriname dan Amerikan Serikat (Wahyono, Rudi dan Marzuki, 2010).

Kerupuk adalah suatu jenis makanan kering yang terbuat dari bahan-bahan yang mengandung pati cukup tinggi. Pengertian lain menyebutkan bahwa kerupuk merupakan jenis makanan kecil yang mengalami pengembangan volume membentuk produk yang porus dan mempunyai densitas rendah selama proses penggorengan. Demikian juga produk ekstrusi akan mengalami pengembangan pada saat pengolahannya (Wahyono, Rudi dan Marzuki, 2010).

Pengembangan kerupuk merupakan proses ekspansi tiba-tiba dari uap air dalam struktur adonan sehingga diperoleh produk yang volumenya mengembang dan porus. Pada dasarnya kerupuk mentah diproduksi dengan gelatinisasi pati adonan pada tahap pengukusan, selanjutnya adonan dicetak dan dikeringkan. Pada proses penggorengan akan terjadi penguapan air yang terikat dalam gel pati akibat peningkatan suhu dan dihasilkan tekanan uap yang mendesak gel pati sehingga terjadi pengembangan dan sekaligus terbentuk rongga-rongga udara pada kerupuk yang telah digoreng (Koswara, 2009).

Secara garis besar proses pembuatan kerupuk sebagai berikut : pencampuran bahan baku, pembuatan adonan, pembentukan/ pencetakan adonan, pengukusan, pendinginan, pengirisan, pengeringan dan penggorengan (untuk produk mentah cukup sampai proses pengeringan). Komposisi atau perbandingan bahan yang digunakan tidak pernah diseragamkan, jadi tergantung dari selera produsen. Sumber bahan baku yang digunakan untuk membuat kerupuk adalah bahan pangan dengan kandungan karbohidrat yang cukup tinggi, yaitu pati. Pati yang digunakan sebagai 
bahan baku dalam pembuatan kerupuk disebut sebagai puffable material. Puffable material adalah bahan yang memegang peranan utama dalam proses pemekaran produk. Bahan tambahan yang digunakan yaitu sebagai bahan penimbul cita rasa, berupa bahan pangan yang mengandung protein, lemak, penambah rasa manis, rasa gurih dan air untuk membentuk adonan kerupuk (Koswara, 2009).

Selain itu, pengemasan juga untuk mempermudah penanganan serta distribusi dan memperpanjang masa simpan produk yang dikemas. Syarief (1989) menerangkan bahwa terdapat hubungan antara kemasan dengan mutuproduk yang dikemas. Pengemas akan menjaga produk dari perubahan aroma, warna, tekstur yang dipengaruhi oleh perpindahan uap air dan oksigen.

Berdasarkan hasil penelitian dari Wulandari, Waluyo dan Novita (2013) menyatakan bahwa pengemasan kerupuk kemplang dengan plastik polipropilen dengan ketebalan 0,5-0,7 mm dapat mencegah kerupuk kemplang menjadi mlempem dan berubah teksturnya menjadi liat. Dengan menggunakan kemasan polipropilen dengan ketebalan 0,5-0,7 mm dapat mempertahankan kerenyahan dari kerupuk kemplang hingga lebih dari 1 tahun.

\section{METODE PENGABDIAN}

\section{Introduksi Alat Perebus Adonan Kerupuk (Desain alat khusus)}

Proses perebusan adonan kerupuk merupakan proses yang paling krusial dalam pembuatan kerupuk. Hasil perebusan diharapkan adonannya sudah tercetak tipis-tipis dengan ketebalan 2-3 mm sehingga masyarakat posdaya tidak perlu mengiris adonan matang dengan pisau untuk mendapatkan adonan matang dengan ketebalan yang diinginkan. Semakin tipis adonan matang dari kerupuk singkong maka semakin cepat adonan kering dan ketika kerupuk mentah tersebut digoreng akan semakin renyah. Selain itu, dengan alat tersebut diharapkan proses perebusan adonan kerupuk berlangsung lebih cepat sehingga dapat mempercepat proses produksi kerupuk singkong dan dapat meningkatkan kapasitas produksi kerupuk singkong.

Introduksi alat perebus adonan kerupuk dengan desain khusus dimaksudkan untuk mempercepat proses pematangan adonan kerupuk sekaligus mendapatkan adonan kerupuk matang dengan tingkat ketebalan yang diinginkan yaitu 2-3 mm. Alat perebus adonan kerupuk berbahan baku stainless steel dengan kapasitas $1 \mathrm{~kg}$ per alat dengan setiap alat dapat menghasilkan 30 keping kerupuk singkong. Alat perebus adonan kerupuk dengan desain khusus dapat dilihat pada Gambar 3.

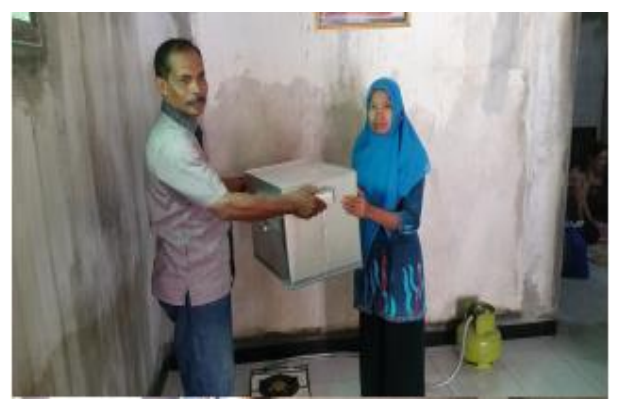

Gambar 2. Serah terima alat pengukus dan pendukung lainnya oleh ketua tim kepada ketua kelompok Posdaya Muslimatan Ar-Rahman.

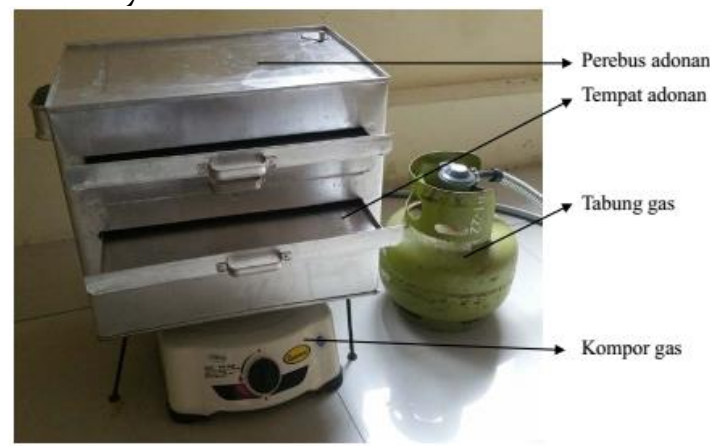

Gambar 3. Alat Perebus Adonan Kerupuk dengan desain khusus 


\section{Introduksi Pengemasan Kerupuk yang Higienis}

Kualitas dari kerupuk ditentukan oleh tingkat kerenyahannya. Untuk menjaga kerenyahan dan cita rasa kerupuk singkong agar dapat bertahan lama atau memiliki masa kadaluarsa yang lebih lama maka diperlukan tehnik pengemasan kerupuk yang tepat. Salah satu bahan pengemas yang sudah teruji melalui beberapa penelitian untuk menjadi bahan pengemas dari kerupuk yang mampu mempertahankan kualitas kerupuk hingga lebih dari satu tahun adalah plastik polipropilen dengan ketebalan 0,7 mm. Untuk itu, kelompok Posdaya Muslimatan Ar-Rahman akan diintroduksikan sebuah sealer plastik (Gambar 4) dan bahan pengemas kerupuk yaitu plastik polipropilen dengan ketebalan $0,7 \mathrm{~mm}$.

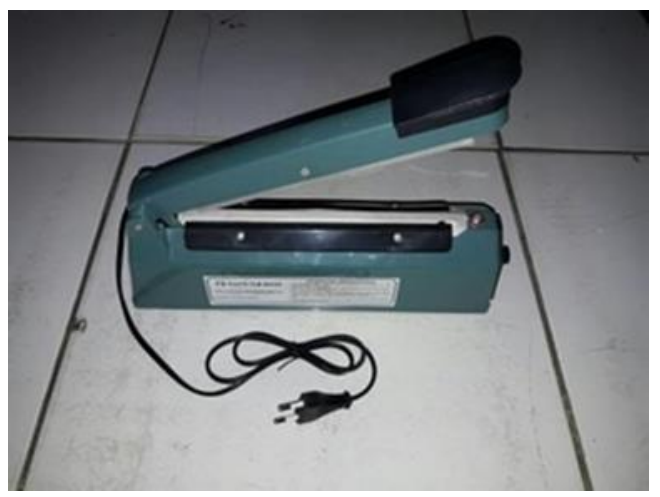

Gambar 4. Sealer Plastik

Pelatihan pendaftaran produk mendapatkan sertifikat P-IRT

Pelatihan pendaftaran produk untuk mendapatkan sertifikat P-IRT menggunakan Power Point yang berisi tentang tata cara mendaftarkan produk untuk mendapatkan sertifikat P-IRT. Dalam pelatihan ini ibu-ibu kelompok Posdaya Muslimatan Ar-Rahman akan mengetahui: (1) persyaratan yang harus dilengkapi untuk melakukan pendaftaran produk untuk sertifikat P-IRT, (2) Alur atau proses pendaftarannya.

\section{Pendampingan}

Kegiatan pendampingan pro- ses produksi kerupuk singkong dengan menggunakan teknologi tepat guna yaitu alat perebus adonan dengan desain khusus, tehnik pengemasan kerupuk singkong yang tepat dan pelatihan pendaftaran produk untuk mendapatkan sertifikat P-IRT dilakukan dalam rangka memberikan motivasi dan praktik ke-pada ibu-ibu kelompok Posdaya Muslimatan Ar-Rahman Desa Candijati kabupaten Jember untuk meningkatkan kualitas dan kuantitas produk kerupuk singkong melalui alat-alat produksi yang telah diberi- kan. Kegiatan ini juga merupakan praktik riil pemberdayaan usaha kecil yang dilakukan oleh tim pengabdian.

\section{Konsulidasi Kegiatan}

\section{HASIL DAN PEMBAHASAN}

Konsulidasi kegiatan pengabdian dilakukan oleh beberapa mahasiswa Fakultas Pertanian Universitas Jember beserta dosen pendamping yang memiliki keahlian dibidang teknologi pangan. Konsulidasi kegiatan dengan Ketua Muslimatan Ar-Rahman desa Candijati Kecamatan Arjasa untuk pemantapan persiapan kegiatan. Kegiatan ini bertujuan untuk mendapatkan informasi kegiatan-kegiatan yang telah dilakukan oleh ibu-ibu muslimatan di Dusun Krajan Desa Candijati (Gambar 5). 


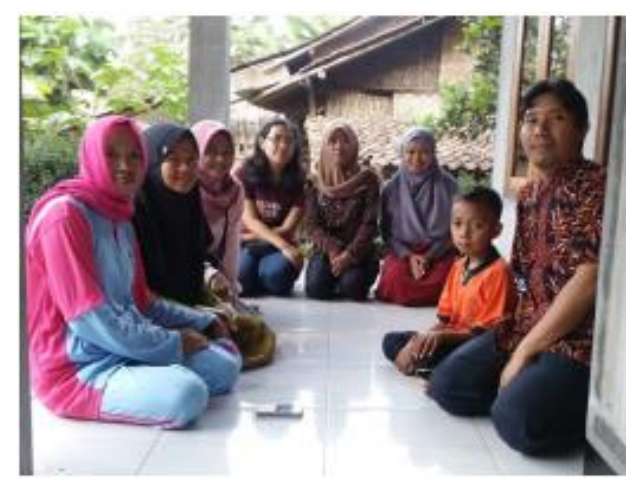

Gambar 5. Konsulidasi dan koordinasi kegiatan oleh Tim dengan Ketua Muslimatan.

\section{Pelatihan Pembuatan Krupuk Berbasis Singkong Higienis}

Ibu-ibu yang tergabung dalam Muslimatan Ar-Rahman sangat antusias sekali dalam mengikuti pelatihan awal pembuatan krupuk berbasis singkong, sehingga untuk program ini dipilih beberapa orang yang relatif muda dan sangat berkeinginan untuk mengembangkan potensinya dibidang produksi krupuk. Hasil pemilihan peserta pelatihan diperoleh sepuluh orang yang diharapkan menjadi pionir atau pelopor pertama produksi krupuk di desa Candijati (Gambar 6) . Dari 10 orang itu, akan mengembangkan usaha dengan mengajak ibu disekitarnya untuk berwirausaha.

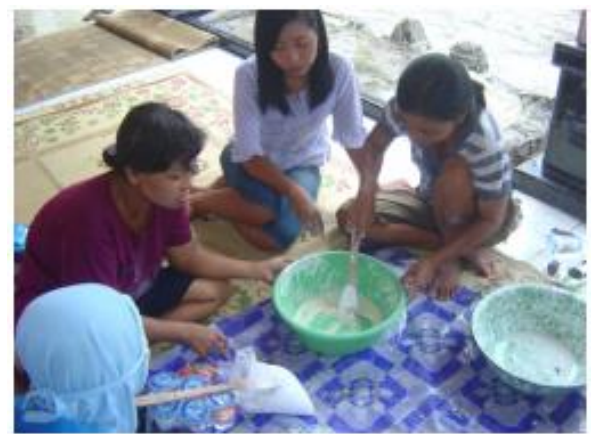

A

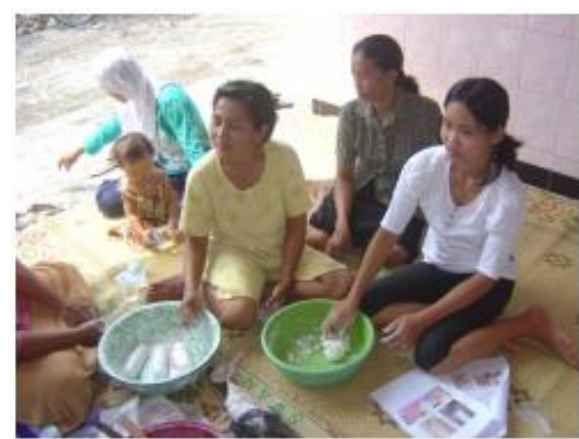

B

Gambar 6. A dan B Pelatihan pembuatan krupuk berbahan baku tepung tapioka terhadap ibu-ibu muda yang memiliki waktu senggang dan diharapkan menjadi cikal bakal wirausaha produksi krupuk.

\section{Introduksi Alat Perebus Adonan Kerupuk}

Dalam upaya menunjang kegiatan usaha produksi krupuk adalah memberikan beberapa peralatan pendukung seperti bak pengaduk adonan, pengaduk adonan, gunting pemotong krupuk, pencetak krupuk dan alat-alat lainnya (Gambar 3; Gambar 4; Gambar 7). Produksi krupuk yang merupakan usaha rumah tangga untuk mendukung perekonomian rumah tangga sehingga diperlukan peralatan sederhana untuk ditempatkan dimasing-masing keluarga.

Dalam upaya mengatur jumlah krupuk yang diproduksi, masing-masing keluarga diberikan sejumlah bahan untuk membuat krupuk, sehingga tidak ada perbedaan dari masing-masing keluarga dari segi kualitas bahan yang digunakan. Strategi pengaturan produksi krupuk mengikuti alur:

1. Ketua kelompok usaha memberikan bahan berupa tepung tapioka.

2.Anggota berfungsi sebagai pengolah setengah jadi sampai menjadi adonan.

3. Proses pemotongan dan penjemuran krupuk dilakukan di rumah ketua. 


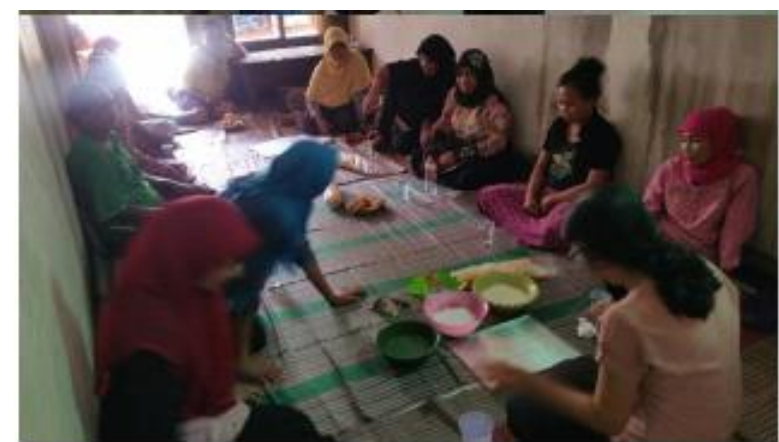

Gambar 7. Pelatihan produksi krupuk tanpa bahan pengawet pada beberapa anggota kelompok Muslimat Ar-Rahman di Dusun Krajan Barat.

Peralatan penunjang yang dihibahkan kepada kelompok yaitu alat perebus krupuk berbasis singkong dengan tenaga pembakar gas LPG. Penggunaan alat perebus ini dapat menggantikan teknologi sebelumnya yang membutuhkan waktu lama untuk menghasilkan krupuk mentah. Dalam teknologi ini tahapan yang dihilangkan yaitu proses pemotongan krupuk menggunakan pasrah. Perebus krupuk ini sangat mudah dan efisien bagi ibu-ibu karena memiliki teknologi sederhana yang tidak membutuhkan banyak prosedur dalam pengoperasiannnya. Hasil uji coba peralatan perebus ini sangat baik untuk pembuatan krupuk dan sangat cepat masak.

Manfaat kegiatan PKM ini yaitu:

1. Produksi krupuk menjadi lebih higienis karena semua kegiatan dilakukan dengan menggunakan alat bantu atau tidak banyak menggunakan alat tangan secara langsung.

2. Alat pengukus ini mampu mempercepat prases pemasakan asonan sehingga jumlah produksi dapat ditingkatkan.

3. Kemasan merupakan salah satu daya tarik terhadap konsumen sehingga dengan perbaikan kemasan maka nilai jual akan lebih tinggi.

4. Peningkatan Produksi dari 20 menjadi 50 bungkus dengan rata-rata keuntungan per bungkus Rp. 23.540,-.

5. Alat pengukus krupuk ini merupakan teknologi tepat guna yang sangat efisien, perawatannya mudah dan harganya sangat murah.

Sebelum pelaksanaan pelatihan operasional penggunaan alat pengukus ini, hasil uji coba menunjukkan bahwa krupuk yang dihasilkan memiliki ketebalan yang sangat bagus, sehingga apabila krupuk digoreng maka tekturnya sangat renyah dan lunak.

Dengan menggunakan alat ini, inovasi produk dapat dikembangkan menjadi berbagai macam bentuk krupuk yang lucu dan sesuai untuk anak-anak, yaitu membentuk krupuk dengan berbagai macam bentuk karakter kartun. Krupuk yang dihasilkan oleh mesin perebus ini memiliki kualitas yang bagus dan mampu menambah kapasitas produksi krupuk berbasis singkong.

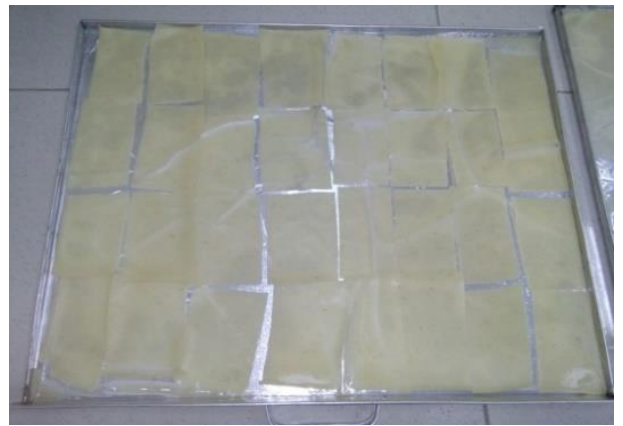

Gambar 8. Adonan Kerupuk yang baru dikeluarkan dari Alat Perebus Adonan Kerupuk 


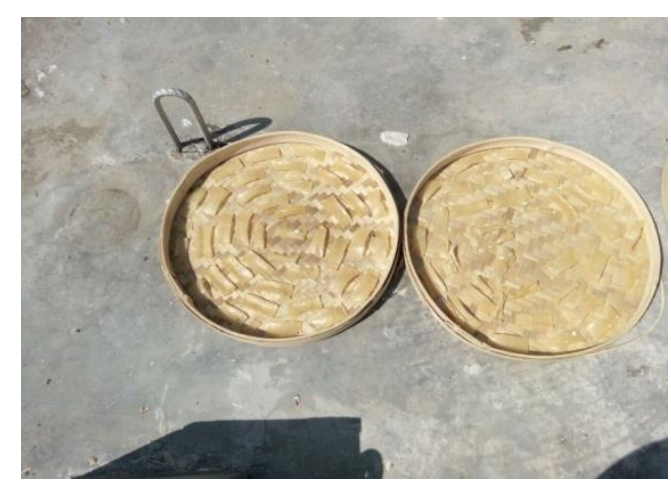

Gambar 9. Adonan Kerupuk yang sudah kering

\section{Pelatihan pendaftaran produk mendapatkan sertifikat P-IRT}

Kegiatan pelatihan pendaftaran produk untuk mendapatkan sertifikat P-IRT ditekankan pada persyaratan yang harus disiapkan dan alur pendaftaran produk ke dinas kesehatan hingga mendapat sertifikat P-IRT.

Hasil yang telah diperoleh dari kegiatan pelatihan tersebut adalah tim pengabdian telah memotivasi dan menyakinkan para anggota kelompok Posdaya Muslimatan Ar-Rahman bahwa pendaftaran produk ke dinas kesehatan untuk mendapatkan sertifikat P-IRT harus dilakukan untuk membantu meningkatkan kualita dari produk kerupuk singkong yang dijual dan meningkatkan kepercayaan konsumen terhadap kualitas dari produk kerupuk singkong yang dijual oleh anggota kelompok Posdaya Muslimatan Ar-Rahman.

\section{Kesimpulan}

\section{PENUTUP}

Berdasarkan kegiatan pengabdian masyarakat yang telah dilakukan dapat disimpulkan sebagai berikut.

1. Pemberian pelatihan pembuatan kerupuk menggunakan teknologi alat perebus mampu meningkatkan pendapatan, kesejahteraan anggota kelompok, dan membuka lapangan kerja baru.

2. Produksi krupuk menjadi lebih higienis, lumlah produksi dapat ditingkatkan, dan perbaikan kemasan

3. Peningkatan produksi dari 20 menjadi 50 bungkus dengan rata-rata keuntungan per bungkus Rp. 23.540,-

\section{Saran}

Program Kemitraan Masyarakat merupakan program yang tepat bagi pemberdayaan ekonomi masyarakat petani, dengan memberikan fasilitas, pelatihan dan pendampingan. Untuk lebih meningkatkan dan memantapkan program tersebut, maka perlunya pendampingan dana, pelatihan, dan pengawasan secara intensif terhadap program yang telah dicanangkan, sehingga masyarakat yang telah dibina menjadi lebih mantap dalam manjalankan usaha untuk meningkatkan pendapatan dan kesejahteraan.

\section{DAFTAR PUSTAKA}

Koswara, Sutrisno. 2009. Pengolahan Aneka Kerupuk. www. Ebookpangan.com. Diakses Tanggal 09 November 2017.

Permendagri RI Nomor 7 Tahun 2007 tentang Kader Pemberdayaan Masyarakat, Bandung : Fokus Media.

Sutoro, Eko. 2002. Pemberdayaan Masyarakat Desa, Materi Diklat Pemberdayaan Masyarakat Desa, yang diselenggarakan Badan Diklat Provinsi Kaltim. Samarinda. Desember 2002. 
Syarief, R. 1989. Teknologi Pengemasan Pangan PAU Pangan dan Gizi. Bogor : IPB Bogor.

Wahyono, Rudy, dan Marzuki. 2010. Pembuatan Aneka Kerupuk. Jakarta: Penebar Swadaya.

Wulandari, A., S. Waluyo, dan D. D. Novita. 2013. “ Prediksi Umur Simpan Kerupuk Kemplang Dalam Kemasan Plastik Polipropilen Beberapa Ketebalan”. Fakultas Pertanian Universitas Lampung. Lampung. 